\title{
REGISTER BAHASA MASYARAKAT PETANI DESA KUTA KECAMATAN BELIK KABUPATEN PEMALANG
}

\author{
Mulasih $^{1}$, Yukshan Wakhyudi ${ }^{2}$ \\ Universitas Peradaban Bumiayu \\ Mulasih_tary@yahoo.com ${ }^{1}$ \\ zafranalyukhsan@gmail.com ${ }^{2}$
}

\begin{abstract}
ABSTRAK
Masyarakat petani sebagai masyarakat pemakai bahasa memiliki cara khusus untuk menyampaikan pengetahuannya melalui bahasa. Masyarakat petani banyak menggunakan kata, ungkapan, atau konsep yang hanya dipahami oleh masyarakat atau kelompoknya sendiri, sehingga di dalam masyarakat petani terdapat bahasa-bahasa khusus. Istilah sosiolinguistik bahasa khusus ini dikenal dengan register. Register masyarakat petani ini menyangkut bidang pekerjaan yang sedang mereka lakukan. Tujuan penelitian ini adalah untuk mengetahui wujud register masyarakat petani. Penelitian ini menggunakan pendekatan kualitatif. Sumber data diambil dari semua bentuk percakapan bahasa yang digunakan dalam masyarakat petani desa Kuta, Kecamatan Belik, Kabupaten Pemalang. Metode dan teknik pengumpulan data yang digunakan adalah metode observasi atau pengamatan, sedangkan tekniknya meliputi teknik wawancara dan pencatatan. Hasil rekaman ditranskripsi dalam bentuk tulisan kemudian dianalisis dalam kartu data, dan diklasifikasikan tuturan-tuturan yang mengandung register berdasarkan aspek yang akan dikaji atau diteliti. Berdasarkan hasil pengkajian dalam penelitian ini, penulis menyarankan kepada pemerhati dan pencinta bahasa diharapkan dapat meneliti lebih lanjut selain register tentang bahasa petani. Oleh karena itu, perlu adanya perhatian lebih lanjut tentang register yang digunakan oleh masyarakat petani, terutama untuk mengetahui tujuan register yang digunakan oleh masyarakat petani didaerah lain agar dapat membandingkan dan menambah pengetahuan tentang register terutama bagi masyarakat petani itu sendiri.
\end{abstract}

Kata kunci; Register, bahasa, petani

\section{A. PENDAHULUAN}

Desa Kuta berada di daerah Kecamatan Belik. Letaknya berada di dekat kaki Gunung Slamet Jawa Tengah. Mayoritas penduduk desa Kuta, bermata pencaharian sebagai petani. Masyarakat yang masih memegang teguh pada tradisi lama, terdapat cara untuk menyampaikan pengetahuannya melalui bahasa. Bahasa Jawa yang merupakan bahasa mereka sehari-hari, memiliki peranan yang sangat fungsional. Peranan ini terlihat dalam segala aspek kehidupan mereka, seperti dalam tegur menegur, berbasa-basi, dalam perjumpaan di jalan, di rumah, waktu bertemu, menyebut alat-alat dalam perlengkapın, dan lain-lain. 
Lingua Rima: Jurnal Pendidikan Program Studi Bahasa dan Sastra Indonesia

Vol.8 No.1 Januari 2019

Interaksi sosial dalam masyarakt dapat mengakibatkan kontak bahasa yang terjadi pada berbagai ragam bahasa. Keadaan tersebut berlanjut pada penggunaan ragam bahasa maka penguasaan ragam bahasa semakin bervariasi dan terjadi pada masyarakat diberbagai lapisan masyarakat (Wahab, 2013:148).

Kekayaan bahasa dalam masyarakat desa Kuta yang mungkin belum tentu dimiliki masyarakat yang lainnya merupakan hal menarik untuk melestarikan budaya berbahasa yang berbudi luhur. Penulis akan mengadakan studi bagaimana norma-norma dan nilai-nilai sosial mempengaruhi perilaku linguistik pada pemakaian bahasa masyarakat petani yang memiliki ciri dan sifat khusus itu. Penelitian ini bertujuan untuk Mengetahui wujud register yang dipakai oleh masyarakat petani di desa Kuta.

\section{B. KAJIAN TEORI}

Bahasa dikatakan tidak homogen karena dalam keadaannya bahasa merupakan bagian dari masyarakat dan kebudayaan tertentu. Realisasinya berujud variasi-variasi tuturan yang beraneka ragam sesuai dengan keanekaragaman masyarakat bahasa, serta sifat-sifat khusus yang ada pada masing-masing penuturnya. Adapun wujud variasi itu dapat berupa idiolek, dialek, ragam bahasa, register, maupun unda usuk. Pemakaian register ini sangat penting untuk menyelaraskan situasi bahasa seseorang dengan rekan bicaranya atau penulis dengan pembacanya.

Trudgil (1974: 104) mengungkapkan register adalah variasi bahasa yang berhubungan dengan pekerjaan atau dalam situasi kerja. Maka, register adalah variasi bahasa berdasarkan pekerjaan. Register ditandai oleh perbedaan kosa kata. Misalnya dalam pemakaian kata-kata khusus dan biasanya perbedaan antara register yang satu dengan lain berdasarkan perbedaan leksikon, lebih lanjut dijelaskan. Menurut Nababan (dalam Wahab, 2015:153) bahwa di Indoneisa terdapat istilah bahasa gado-gado untuk pemakaian bahasa campuran antara bahasa Indonesia dan bahasa daerah.

Ferguson melihat diglosia hanya sebagai adanya pembedaan fungsi ragam tinggi dan rendah dalam sebuah bahasa, maka Fishman melihat diglosia sebagai adanya pembedaan fungsi, mulai dari pembedaan stilistik dari sebuah bahasa sampai adanya perbedaan fungsi dari dua buah bahasa yang berbeda. Jadi, di dalamnya termasuk antara dialek, register, atau variasi bahasa secara fungsional Fishman dalam Chaer (1995: 133) mengembangkan konsep diglosia ini menjadi apa yang disebut dengan broad diglosia (diglosia luas). Di dalam konsep broad diglosia perbedaan dialek itu tidak hanya antara dua bahasa atau dua ragam atau dialek itu. Dengan demikian juga keadaan masyarakat yang di dalamnya ada diperbedakan tingkatan fungsi 
Lingua Rima: Jurnal Pendidikan Program Studi Bahasa dan Sastra Indonesia

Vol.8 No.1 Januari 2019

kebahasaan, sehingga muncullah apa yang disebut double overlapping diglosia, double -nested diglosia, dan linier polyglosia.

Overlapping diglosia adalah situasi pembedaan derajat dan fungsi bahasa secara berganda sedangkan yang dimaksud double-nested diglosia adalah keadaan dalam masyarakat multilingual. Double-nested diglosia yang terdapat dua bahasa yang dibedakan yaitu satu sebagai bahasa-bahasa tinggi dan yang lain sebagai bahasa rendah, tetapi baik bahasa tinggi maupun bahasa rendah itu. Setiap ragam atau dialek masing-masing mempunyai ragam atau dialek masing-masing, juga diberi status sebagai ragam tinggi dan ragam rendah.

\section{METODE PENELITIAN}

Pendekatan penelitian yang digunakan dalam penelitian ini, yaitu pendekatan secara metodologis. Pendekatan metodologis dalam penelitian ini meliputi dua pendekatan, yaitu pendekatan kualitatif dan pendekatan deskriptif. Pendekatan kualitatif adalah suatu pendekatan penelitian yang tidak mengadakan perhitungan sementara itu pendekatan deskriptif adalah pendekatan penelitian yang dilakukan semata-mata hanya berdasarkan fakta yang ada atau fenomena yang secara empiris hidup pada penuturnya, sehingga yang dihasilkan berupa perian bahasa seperti apa adanya (Sudaryanto, 1992: 62).

Lokasi penelitian ini adalah desa Kuta kecamatan Belik kabupaten Pemalanag yang memiliki kekhasan bahasa yang dipakai masyarakat petani tersebut. Sumber data penelitian register bahasa petani ini adalah semua bentuk bahasa yang digunakan dalam masyarakat petani. Data penelitian ini berupa percakapan masyarakat petani dalam bahasa sehari-hari.

Berdasarkan penelitian yang akan dilakukan maka digunakan teknik pengumpulan data yaitu teknik observasi atau pengamatan dilakukan dengan mengamati bentuk kebahasaan yang digunakan oleh masyarakat petani kemudian mencatat hal-hal yang diperlukan dalam pengumpulan data. Data yang telah dikumpulkan dan diatur atau diklasifikasikan kemudian dianalisis yaitu diuraikan, dipilah dan dibedakan unsur-unsur yang membentuk satuan-satuan lingual atau mengenai suatu satuan lingual ke dalam komponen-komponennya.

\section{PEMBAHASAN}

Kuta adalah nama desa di kota Pemalang yang sebagian penduduknya bermata pencaharian sebagian seorang petani. Suasana atau situasi pada masyarakat petani menggambarkan ciri khas kehidupan masyarakat khususnya pada saat melakukan kegiatan-kegiatan di tempat tertentu, kebanyakan dari mereka dalam komunikasi menggunakan ragam bahasa sesuai dengan kegiatan yang mereka lakukan pada tempat itu. 
Lingua Rima: Jurnal Pendidikan Program Studi Bahasa dan Sastra Indonesia

Vol.8 No.1 Januari 2019

\section{Register Bahasa Pada Masyarakat Petani Desa Kuta}

Ragam bahasa itu dipakai oleh masyarakat petani disesuaikan dengan kegiatan dan tempat tertentu. Macam-macam register yaitu register kedokteran, register ekonomi, register perdagangan, register warian, register petani dan sebagainya. Contoh kegiatan yang menggambarkan pemakaian register dalam masyarakat :

a. Konteks Percakapan yang Membicarakan Kegiatan Sebagai Istri Petani Tri :"Piwe yu? .......jam pira bojomu gone bali. Terus parine didalah ningendi bae. Kayong olih akeh temen gole panen.

(Bagaimana Mbak? pukul berapa suamimu pulang. Lalu, padinya ditaruh dimana saja, kayaknya banyak sekali panenya,)

Eti: "Tekan mbengi koh. Ya parine dianjingaken ngumah kabeh, kebek umahe deng pari,"

(Sampai malam. Iya, padinya dimasukkan ke rumah semua, sampai sesak rumahnya,)

Kata 'didalah' ( ditaruh) 'anjingaken' (dimasukkan). Kata-kata tersebut sebagai bentuk register yang menggambarkan bentuk umum kegiatan situasi dan keadaan yang ada dan dilakukan oleh para petani.

b. Konteks Percakapan Masyarakat yang Membicarakan Kegiatan Ronda

Turhadi : "Lho, kowe mbengi maringendi, ora mangkat ronda apa?”.

(Kamu semalam kemana, nggak berangkat ngeronda?)

Waryono: "Aku kesel banget koh, langsung tebluk ringamben."

(Aku capek banget, langsung tidur di ranjang)

Kata 'tebluk' (tidur) kata tersebut sebagai bentuk register yang menggambarkan bentuk umum kegiatan situasi dan keadaan yang ada dan dilakukan oleh masyarakat di desa Kuta.

c. Konteks Percakapan Masyarakat saat berbelanja di Warung

Uus : "Gone tuku sarimi akeh temen, apa bakale entong kue?"

(Beli mie instannya banyak sekali, apa kiranya habis)

Ma'in : "Ya nggo pranti, wong selerane donganu sejen-sejen wong seumah."

(Ya untuk persediaan, soalnya selera orang serumah beda-beda)

Kata 'sarimi' (mie instan) kata tersebut sebagai bentuk register yang menggambarkan bentuk umum kegiatan situasi dan keadaan yang ada dan dilakukan oleh para petani di desa Kuta. Kebanyakan orang di Desa Kuta menyebut semua jenis mie instan itu sarimi. 
Lingua Rima: Jurnal Pendidikan Program Studi Bahasa dan Sastra Indonesia

Vol.8 No.1 Januari 2019

\section{Faktor Sosial Budaya yang Melatarbelakangi Pemakaian Register Masyarakat Petani}

Kehidupan sehari-hari yang dilakukan masyarakat petani sebagai masyarakat bahasa yang menggunakan bahasa secara beragam dengan pilihan bahasa yang beragam pula, munculnya keragaman ini tentunya ada faktor yang melatarbelakangi pemakaian register yang dipakai pada masyarakat petani antara lain adalah Tempat dan Situasi di mana mereka tinggal. Desa Kuta adalah nama desa di kota Pemalang yang sebagian penduduknya bermata pencaharian sebagian seorang petani. Suasana atau situasi pada masyarakat petani menggambarkan ciri khas kehidupan masyarakat khususnya pada saat melakukan kegiatan-kegiatan di tempat tertentu, kebanyakan dari mereka dalam komunikasi menggunakan ragam bahasa khusus sesuai dengan kegiatan yang mereka lakukan pada tempat itu. Ragam bahasa itu dipakai oleh masyarakat petani disesuaikan dengan kegiatan dan tempat tertentu.

\section{E. SIMPULAN}

Simpulan yang disajikan dari pembahasan menunjukkan bahwa register yang digunakan masyarakat Desa Kuta yang mayoritas petani sebagai masyarakat profesi, memiliki beberapa bentuk. Ada beberapa hal yang melatarbelakangi pemakaian register masyarakat petani yaitu: tempat dan situasi, peserta tutur, topik pembicaraan yang berupa topik tertentu sesuai dengan kebutuhan mereka, norma kebudayaan yaitu kebiasaan masyarakat petani. Berdasarkan hasil pengkajian dalam penelitian ini, penulis menyarankan kepada pemerhati dan pencinta bahasa diharapkan dapat meneliti lebih lanjut selain register tentang bahasa petani. Oleh karena itu, perlu adanya perhatian lebih lanjut tentang register yang digunakan oleh masyarakat petani, terutama untuk mengetahui tujuan register yang digunakan oleh masyarakat petani didaerah lain agar dapat membandingkan dan menambah pengetahuan tentang register terutama bagi masyarakat petani itu sendiri.

\section{F. DAFTAR PUSTAKA}

Chaer, Abdul, Agustina. 1995. Sosiologi Pengantar Awal. Jakarta: Rineka Cipta.

Sudaryanto. 1995. Aneka Penelitian Bahasa dan Sastra. Yoyakarta: Sanata Dharma University.

Trudgil, Peter. 1979. Sociolinguistycs an Introduction. England: Penguin Books LTD.

Wahab, Laode Abdul. 2013. Fenomena Diglosia dalam Masyarakat Keturunan Arab Empang. Al Izzah:Jurnal Hasil-Hasil Penelitian. IAIN Kendari. Volume 8 No 22013 PP. 147-165 http://ejournal.iainkendari.ac.id/al-izzah/article/view/172 
Lingua Rima: Jurnal Pendidikan Program Studi Bahasa dan Sastra Indonesia

Vol.8 No.1 Januari 2019

. 2105. Pilihan Bahasa pada Komunitas Tutur Pasar Baruga. Al Izzah:Jurnal HasilHasil Penelitian. IAIN Kendari. Volume 10 No $2 \quad 2015$ PP. 149-169 http://ejournal.iainkendari.ac.id/al-izzah/article/view/342/328 